\title{
Phase transformation in $\mathrm{CeO}_{2}-\mathrm{Co}_{3} \mathrm{O}_{4}$ binary oxide under reduction and calcination pretreatments
}

\author{
Chih-Wei Tang, ${ }^{\mathrm{a}, \mathrm{b}}$ Wen-Yueh Yu, ${ }^{\mathrm{b}}$ Chin-Jung Lin, ${ }^{\mathrm{b}}$ Chen-Bin Wang, ${ }^{\mathrm{a}, *}$ and Shu-Hua Chien ${ }^{\mathrm{b}, \mathrm{c}, *}$ \\ ${ }^{a}$ Department of Applied Chemistry and Materials Science, Chung Cheng Institute of Technology, National Defense University, \\ Tahsi, Taoyuan, 33509 Taiwan, ROC \\ ${ }^{\mathrm{b}}$ Institute of Chemistry, Academia Sinica, Taipei, 11529 Taiwan, ROC \\ ${ }^{\mathrm{c}}$ Department of Chemistry, National Taiwan University, Taipei, 10617 Taiwan, ROC
}

Received 27 March 2007; accepted 27 March 2007

\begin{abstract}
The $\mathrm{CeO}_{2}-\mathrm{Co}_{3} \mathrm{O}_{4}$ binary oxide was prepared by impregnation of the high surface area $\mathrm{Co}_{3} \mathrm{O}_{4}$ support $\left(\mathrm{S}\right.$.A. $\left.=100 \mathrm{~m}^{2} \mathrm{~g}^{-1}\right)$ with cerium nitrate $\left(20 \mathrm{wt} \%\right.$ cerium loading on $\mathrm{Co}_{3} \mathrm{O}_{4}$ ). Pretreatment of $\mathrm{CeO}_{2}-\mathrm{Co}_{3} \mathrm{O}_{4}$ binary oxide was divided both methods: reduction (under 200 and $400{ }^{\circ} \mathrm{C}$, assigned as $\mathrm{CeO}_{2}-\mathrm{Co}_{3} \mathrm{O}_{4}-\mathrm{R} 200$ and $\mathrm{CeO}_{2}-\mathrm{Co}_{3} \mathrm{O}_{4}-\mathrm{R} 400$ and calcination (under 350 and $550{ }^{\circ} \mathrm{C}$, assigned as $\mathrm{CeO}_{2}-\mathrm{Co}_{3} \mathrm{O}_{4}-\mathrm{C} 350$ and $\mathrm{CeO}_{2}-\mathrm{Co}_{3} \mathrm{O}_{4}-\mathrm{C} 550$ ). The binary oxides were investigated by means of X-ray diffraction (XRD), nitrogen adsorption at $-196{ }^{\circ} \mathrm{C}$, infrared (IR), transmission electron microscopy (TEM), diffuse reflectance spectroscopy (DRS) and temperature programmed reduction (TPR). The results showed that the binary oxides pretreatment under low-temperatures possessed larger surface area. The cobalt phase of binary oxides also was transferred upon the treating temperature, i.e., the $\mathrm{CeO}_{2}-$ $\mathrm{Co}_{3} \mathrm{O}_{4}-\mathrm{R} 200$ binary oxide exhibited higher surface area (S.A. $=109 \mathrm{~m}^{2} \mathrm{~g}^{-1}$ ) and the main phase was $\mathrm{CeO}_{2}, \mathrm{Co}_{3} \mathrm{O}_{4}$ and $\mathrm{CoO}$. While, the $\mathrm{CeO}_{2}-\mathrm{Co}_{3} \mathrm{O}_{4}-\mathrm{R} 400$ binary oxide exhibited lower surface area (S.A. $=40 \mathrm{~m}^{2} \mathrm{~g}^{-1}$ ) and the main phase was $\mathrm{CeO}_{2}, \mathrm{CoO}$ and $\mathrm{Co}$. Apparently, the optimized pretreatment of $\mathrm{CeO}_{2}-\mathrm{Co}_{3} \mathrm{O}_{4}$ binary oxide can control both the phases and surface area.
\end{abstract}

KEY WORDS: $\mathrm{CeO}_{2}-\mathrm{Co}_{3} \mathrm{O}_{4}$ binary oxide; phase transformation; X-ray diffraction.

\section{Introduction}

Transition metal oxides are becoming more important in several fields of materials technology, i.e., carbon dioxide lasers [1], catalytic combustion [2], mine rescue devices [3] and the $\mathrm{CO}$ sensor [4]. This importance promotes studies purpose for better understanding of the surface reactivity of metal oxides.

Low temperature abatement of carbon monoxide is important in environmental pollution control [5]. There are several reports describing the use of noble metals for $\mathrm{CO}$ oxidation at ambient temperatures [6-10]. In order to lower the price, considerable attention has been paid to various transition metal oxides and mixed metal oxides. Among these metal oxides, cobaltic oxide $\left(\mathrm{Co}_{3} \mathrm{O}_{4}\right)$ is very attractive for the presence of mobile oxygen in $\mathrm{Co}_{3} \mathrm{O}_{4}$ [9-11]. The high activity of $\mathrm{Co}_{3} \mathrm{O}_{4}$ on $\mathrm{CO}$ oxidation is likely to be due to the relatively low $\Delta \mathrm{H}$ of vaporization of $\mathrm{O}_{2}[12,13]$. This means that the $\mathrm{Co}-\mathrm{O}$ bond strength of $\mathrm{Co}_{3} \mathrm{O}_{4}$ is relatively weak, leading to provide easily reactive oxygen from the lattice oxygen. In our studies, we also observe that the activity of $\mathrm{Co}_{3} \mathrm{O}_{4}$ toward $\mathrm{CO}$ oxidation is enhanced significantly by increasing the surface area (S.A.) [10]. This means that increasing the S.A. of $\mathrm{Co}_{3} \mathrm{O}_{4}$ mainly due to a weakening

\footnotetext{
*To whom correspondence should be addressed.
}

E-mail: chiensh@gate.sinica.edu.tw in the strength of the $\mathrm{Co}-\mathrm{O}$ bond and the acceleration of oxygen desorption from $\mathrm{Co}_{3} \mathrm{O}_{4}$. Thus, many researchers have measured the catalytic activity of $\mathrm{Co}_{3} \mathrm{O}_{4}$ for $\mathrm{CO}$ oxidation $[11,14]$.

Ceria $\left(\mathrm{CeO}_{2}\right)$ has a high oxygen storage capacity and well known catalytic and red-ox properties (couples of $\left.\mathrm{Ce}^{4+} / \mathrm{Ce}^{3+}\right)$, making more oxygen available for the oxidation process [15]. The rapid growth in the applications and the characterization of $\mathrm{CeO}_{2}$-containing catalysts has been documented [16-23]. In particular, the $\mathrm{CuO} / \mathrm{CeO}_{2}$ catalyst was reported to be very active for the complete $\mathrm{CO}$ oxidation and even comparable to noble metals [17]. Good catalytic activity is also observed for high surface area $\mathrm{CoO}_{x} / \mathrm{CeO}_{2}$ composite catalysts [20].

In the previous study, we have proved that the activity of $\mathrm{CeO}_{2}-\mathrm{Co}_{3} \mathrm{O}_{4}$ binary oxide for $\mathrm{CO}$ oxidation is depended on the pretreatments [24]. The most active sample is pretreatment under $200{ }^{\circ} \mathrm{C}$ reduction. Further, the studied object of this work is aimed to understand the correlations between the effect of pretreatment conditions on the $\mathrm{CeO}_{2}-\mathrm{Co}_{3} \mathrm{O}_{4}$ binary oxide and phase transformation of cobalt oxide. The characteristics of materials are employed by means of X-ray diffraction (XRD), nitrogen adsorption at $-196{ }^{\circ} \mathrm{C}$, transmission electron microscopy (TEM), infrared (IR), diffuse reflectance spectroscopy (DRS) and temperature-programmed reduction (TPR). 


\section{Experimental}

\subsection{Preparation of $\mathrm{CeO}-\mathrm{Co}_{3} \mathrm{O}_{4}$ binary oxide}

The high-valence cobalt oxide was synthesized first with precipitation-oxidation method in an aqueous solution, then, refined by a controlled hydrogen reduction in a temperature-programmed reduction system till $230{ }^{\circ} \mathrm{C}$ to get cobaltic oxide. The detailed preparation procedure was described in a previous paper [8].

The $\mathrm{CeO}_{2}-\mathrm{Co}_{3} \mathrm{O}_{4}$ binary oxide was prepared by impregnation of the $\mathrm{Co}_{3} \mathrm{O}_{4}$ support with an aqueous solution of the desired concentration of $\mathrm{Ce}\left(\mathrm{NO}_{3}\right)_{3} 6 \mathrm{H}_{2} \mathrm{O}$ (Aldrich, the ceria loading is $20 \mathrm{wt} \%$ ). The sample was dried at $110^{\circ} \mathrm{C}$ for $24 \mathrm{~h}$, followed by both pretreatment methods: reduction in a $\mathrm{H}_{2}$ stream for $2 \mathrm{~h}$ (under 200 and $400{ }^{\circ} \mathrm{C}$, assigned as $\mathrm{CeO}_{2}-\mathrm{Co}_{3} \mathrm{O}_{4}-\mathrm{R} 200$ and $\mathrm{CeO}_{2}-$ $\mathrm{Co}_{3} \mathrm{O}_{4}-\mathrm{R} 400$ ) and calcination in an air stream (under 350 and $550{ }^{\circ} \mathrm{C}$, assigned as $\mathrm{CeO}_{2}-\mathrm{Co}_{3} \mathrm{O}_{4}-\mathrm{C} 350$ and $\mathrm{CeO}_{2}-\mathrm{Co}_{3} \mathrm{O}_{4}-\mathrm{C} 550$ ) for $4 \mathrm{~h}$.

\subsection{Characterization techniques}

X-ray diffraction (XRD) measurements were performed using Siemens D5000 diffractometer with $\mathrm{Cu}$ $\mathrm{K}_{\alpha 1}$ radiation $(\lambda=1.5405 \mathrm{~A})$ at $40 \mathrm{kV}$ and $30 \mathrm{~mA}$ with a scanning speed in $2 \theta$ of $2^{\circ} \mathrm{min}^{-1}$. Diffraction peaks of crystalline phase were compared with those of standard compounds reported in the JCPDS 2002 data file $\left(\mathrm{Co}_{3} \mathrm{O}_{4}\right.$ : 73-1701; CoO: 71-2391; $\mathrm{Co}: 88-4307 ; \mathrm{CeO}_{2}$ : 81-0792). The crystallite sizes of cobaltic oxide and ceria were estimated using the Scherrer equation.

Nitrogen adsorption isotherms at $-196{ }^{\circ} \mathrm{C}$ were determined volumetrically with Micrometritics ASAP 2010. The catalysts were pre-outgassed at $5 \times 10^{-5}$ Torr for $3 \mathrm{~h}$ at $110{ }^{\circ} \mathrm{C}$. The surface area was determined from the nitrogen adsorption isotherm.

$\mathrm{CeO}_{2}-\mathrm{Co}_{3} \mathrm{O}_{4}$ binary oxides were characterized using TEM (Hitachi H600-3). The samples for the electron microscopy were prepared by making an ethanol suspension and deposited onto an undercoat of a holey carbon film.

The infrared spectra were obtained by a Bomen DA- 8 spectrometer in the range of $500-800 \mathrm{~cm}^{-1}$. One milligram of each powder sample was diluted with $200 \mathrm{mg}$ of vacuum-dried IR-grade $\mathrm{KBr}$ and subjected to a pressure of 8 tons.

The DRS spectra were measured at room temperature on a Hitachi U3410 spectrophotometer equipped with an integration sphere. The spectra were recorded against a $\mathrm{BaSO}_{4}$ standard in the region $200-800 \mathrm{~nm}$.

Reduction behavior of $\mathrm{CeO}_{2}-\mathrm{Co}_{3} \mathrm{O}_{4}$ binary oxides were studied by temperature-programmed reduction (TPR). About $25 \mathrm{mg}$ of the sample was heated in a flow

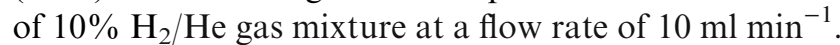
During TPR, the temperature was programmed to rise with $10{ }^{\circ} \mathrm{C} \mathrm{min}^{-1}$ to $550{ }^{\circ} \mathrm{C}$.

\section{Results and discussion}

The XRD patterns of both ceria and cobaltic oxide are shown in figure 1. Based on the diffraction peaks, we can distinguish the phase components of $\mathrm{CeO}_{2}-\mathrm{Co}_{3} \mathrm{O}_{4}$ binary oxide. Figure 2 shows the XRD patterns of $\mathrm{CeO}_{2}-\mathrm{Co}_{3} \mathrm{O}_{4}-\mathrm{C} 350$ and $\mathrm{CeO}_{2}-\mathrm{Co}_{3} \mathrm{O}_{4}-\mathrm{C} 550$. The XRD patterns of $\mathrm{CeO}_{2}-\mathrm{Co}_{3} \mathrm{O}_{4}-\mathrm{R} 200$ and $\mathrm{CeO}_{2}-\mathrm{Co}_{3} \mathrm{O}_{4}-\mathrm{R} 400$ are appeared in figure 3. All samples of XRD profiles show a well-crystallized $\mathrm{CeO}_{2}$ phase with a fluorite-type structure. Besides the $\mathrm{CeO}_{2}$ phase, a separate crystalline $\mathrm{Co}_{3} \mathrm{O}_{4}$ [figures 2(a) and (b) and 3(a)], $\mathrm{CoO}$ [figure 3(a) and (b)] and $\mathrm{Co}$ [figure 3(b)] species are found in the $\mathrm{CeO}_{2}-\mathrm{Co}_{3} \mathrm{O}_{4}$ binary oxides. The degree of crystalline of both phases $\left(\mathrm{Co}_{3} \mathrm{O}_{4}\right.$ and $\left.\mathrm{CeO}_{2}\right)$ increases with increasing calcined temperature [figure 2(a) and (b)], while the crystallite size is similar under 350 and $550{ }^{\circ} \mathrm{C}$ calcined ( $\sim 8 \mathrm{~nm}$ for $\mathrm{Co}_{3} \mathrm{O}_{4}$ and $\sim 6.0 \mathrm{~nm}$ for $\mathrm{CeO}_{2}$ ). Also, the degree of crystalline of mixed phases and $\mathrm{CeO}_{2}$ increases with increasing reduced temperature [figure 3(a) and (b)]. The crystallite size of $\mathrm{CeO}_{2}$ is not affected under low or high reduced temperature $(\sim 6.0 \mathrm{~nm})$, while the effect of treating temperature under reduced atmosphere is apparent for both component and crystallite size. According to the diffraction patterns and the width of the (200) diffraction pattern of $\mathrm{CoO}$ crystalline, the component of $\mathrm{CeO}_{2}-\mathrm{Co}_{3} \mathrm{O}_{4}-\mathrm{R} 200$ [figure 3(a)] is a mixed phases $\left[\mathrm{Co}_{3} \mathrm{O}_{4}\right.$ and $\mathrm{CoO}$, although the (311) peak of $\mathrm{Co}_{3} \mathrm{O}_{4}$ overlap with the (111) peak of $\mathrm{CoO}$, the faint peak of (311) diffraction pattern can be further characterized by TPR] and the crystallite size of $\mathrm{CoO}$ is $8.3 \mathrm{~nm}$. As the reducing temperature increases, the component of $\mathrm{CeO}_{2}-\mathrm{Co}_{3} \mathrm{O}_{4}-\mathrm{R} 400$ shows $\mathrm{CoO}$ and $\mathrm{Co}$ mixed phases and the crystallite size of $\mathrm{CoO}$ grows to $9.4 \mathrm{~nm}$. The components of $\mathrm{CeO}_{2}-\mathrm{Co}_{3} \mathrm{O}_{4}$ binary oxides under different treatments are summarized in the 4 th column of table 1. Slight change of particle size for cobaltic oxide explains that the introducing of ceria can help in improving the dispersion of $\mathrm{Co}_{3} \mathrm{O}_{4}$.

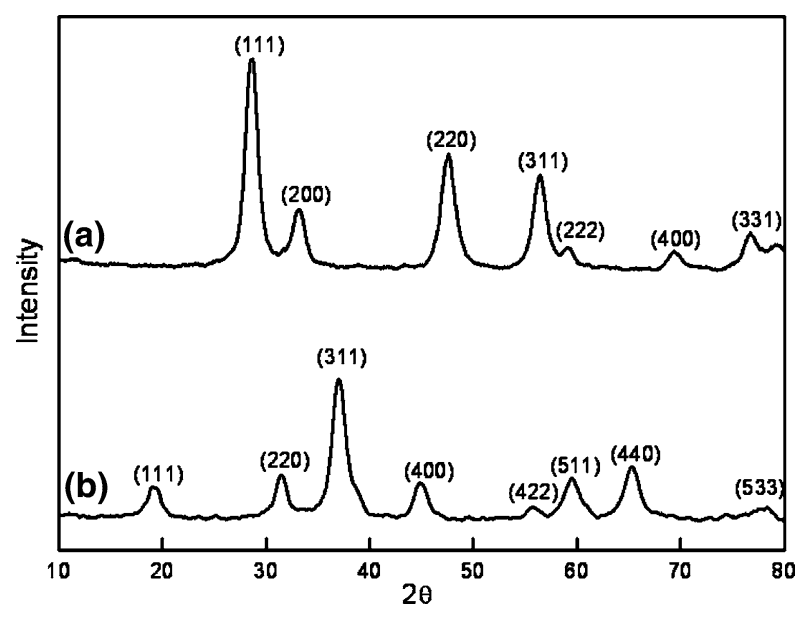

Figure 1. The XRD characterization of ceria and cobaltic oxide: (a) $\mathrm{CeO}_{2}$; (b) $\mathrm{Co}_{3} \mathrm{O}_{4}$. 


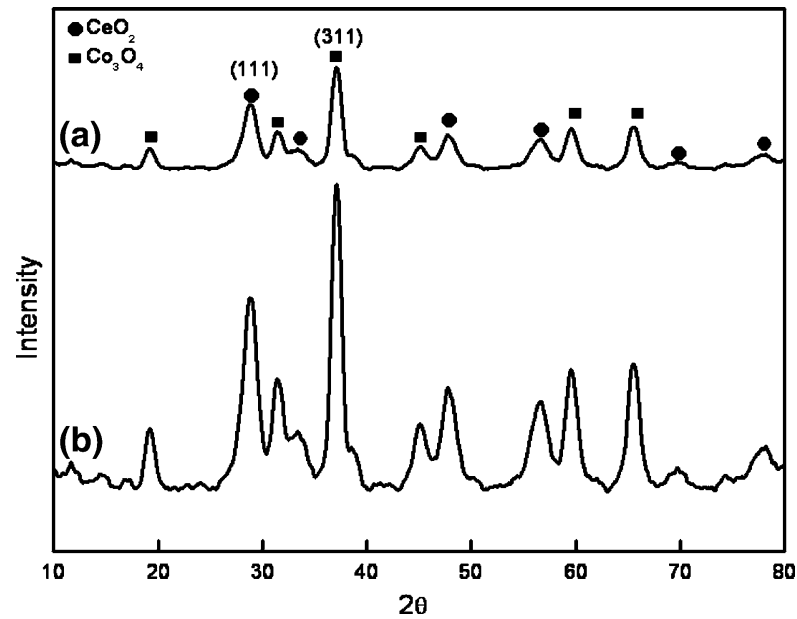

Figure 2. The XRD characterization of $\mathrm{CeO}_{2}-\mathrm{Co}_{3} \mathrm{O}_{4}$ binary oxides: (a) $\mathrm{CeO}_{2}-\mathrm{Co}_{3} \mathrm{O}_{4}-\mathrm{C} 350$; (b) $\mathrm{CeO}_{2}-\mathrm{Co}_{3} \mathrm{O}_{4}-\mathrm{C} 550$.

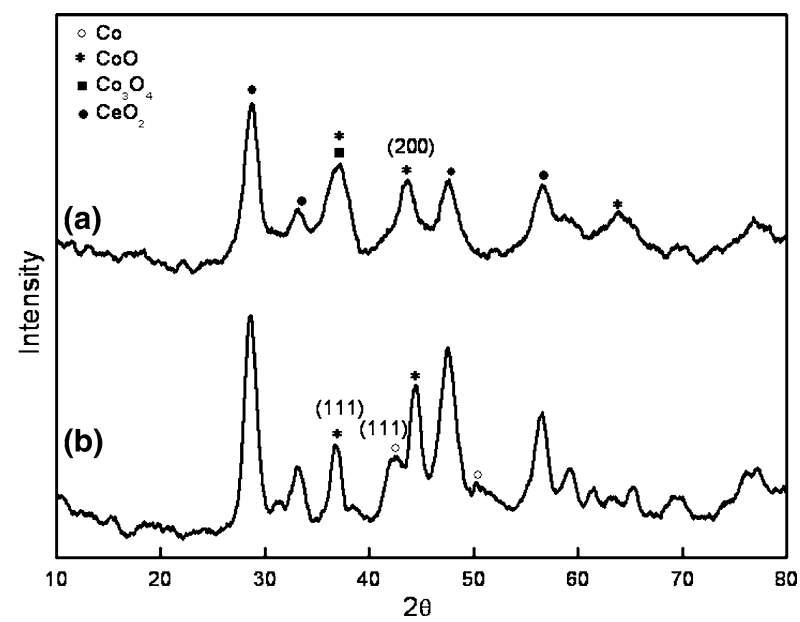

Figure 3. The XRD characterization of $\mathrm{CeO}_{2}-\mathrm{Co}_{3} \mathrm{O}_{4}$ binary oxides: (a) $\mathrm{CeO}_{2}-\mathrm{Co}_{3} \mathrm{O}_{4}-\mathrm{R} 200$; (b) $\mathrm{CeO}_{2}-\mathrm{Co}_{3} \mathrm{O}_{4}-\mathrm{R} 400$.

Figure 4 presents the $\mathrm{N}_{2}$ adsorption-desorption isotherm plots of ceria, cobaltic oxide and the $\mathrm{CeO}_{2}$ $\mathrm{Co}_{3} \mathrm{O}_{4}$ binary oxides at $77 \mathrm{~K}$. Obtained surface areas of $\mathrm{CeO}_{2}-\mathrm{Co}_{3} \mathrm{O}_{4}$ binary oxides are summarized in the 9th

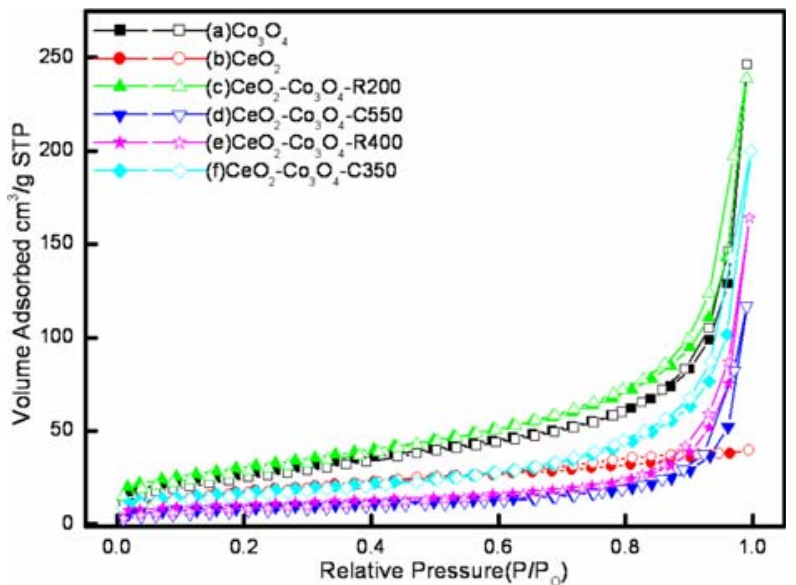

Figure 4. $\mathrm{N}_{2}$ adsorption-desorption isotherm plots of ceria, cobaltic oxide and the $\mathrm{CeO}_{2}-\mathrm{Co}_{3} \mathrm{O}_{4}$ binary oxides.

column of table 1 . The results show that the optimized pretreatment can obtain high surface area of $\mathrm{CeO}_{2}-$ $\mathrm{Co}_{3} \mathrm{O}_{4}$ binary oxide. The increase in treating temperature induces a decrease in its surface area [i.e., $\mathrm{CeO}_{2}-$ $\mathrm{Co}_{3} \mathrm{O}_{4}-\mathrm{C} 550$ (S.A. $\left.=31 \mathrm{~m}^{2} \mathrm{~g}^{-1}\right)<\mathrm{CeO}_{2}-\mathrm{Co}_{3} \mathrm{O}_{4}-\mathrm{C} 350$ (S.A. $\left.=60 \mathrm{~m}^{2} \mathrm{~g}^{-1}\right) ; \mathrm{CeO}_{2}-\mathrm{Co}_{3} \mathrm{O}_{4}-\mathrm{R} 400$ (S.A. $=40 \mathrm{~m}^{2}$ $\left.\mathrm{g}^{-1}\right)<\mathrm{CeO}_{2}-\mathrm{CO}_{3} \mathrm{O}_{4}-\mathrm{R} 200\left(\right.$ S.A. $\left.\left.=109 \mathrm{~m}^{2} \mathrm{~g}^{-1}\right)\right]$. The induced decrease due to the thermal treatment might be attributed to grain growth of the particles or collapse of pores [25]. The smaller nanoparticles of the binary oxide are consistent with the higher surface areas. From the increasing of crystalline and decreasing of surface area of mixed oxides under high temperatures treating condition, a possible explanation was the sintering of nanoparticles. The aggregation of nanoparticles can be observed with the TEM image. Figure 5 shows the TEM images of $\mathrm{CeO}_{2}-\mathrm{Co}_{3} \mathrm{O}_{4}-\mathrm{R} 200$ [figure 5(a)] and $\mathrm{CeO}_{2}-\mathrm{Co}_{3} \mathrm{O}_{4}-\mathrm{R} 400$ [figure 5(b)] samples. Apparently, the dispersion of $\mathrm{CeO}_{2}-\mathrm{Co}_{3} \mathrm{O}_{4}-\mathrm{R} 200$ is better than the $\mathrm{CeO}_{2}-\mathrm{Co}_{3} \mathrm{O}_{4}-\mathrm{R} 400$ (mean particle sizes increase from about 7 to $20 \mathrm{~nm}$ ). The significant aggregation under high temperature reduction induces the decrease of surface area of binary oxide. In order to gain further insight into the microstructural characteristics of the

Table 1

Characterization of $\mathrm{CeO}_{2}-\mathrm{Co}_{3} \mathrm{O}_{4}$ binary oxides

\begin{tabular}{|c|c|c|c|c|c|c|c|c|c|c|c|}
\hline \multirow[t]{3}{*}{ Sample } & \multicolumn{2}{|c|}{ Pretreatments $\left({ }^{\circ} \mathrm{C}\right)$} & \multirow[t]{3}{*}{ Components $^{\mathbf{a}}$} & \multicolumn{4}{|c|}{ Cystalline sizes $(\mathrm{nm})^{\mathbf{b}}$} & \multirow[t]{3}{*}{ S.A. $\left(\mathrm{m}^{2} \mathrm{~g}^{-1}\right)$} & \multicolumn{3}{|c|}{$\operatorname{TPR}\left({ }^{\circ} \mathrm{C}\right)$} \\
\hline & \multirow[t]{2}{*}{ Reduction } & \multirow[t]{2}{*}{ Calcination } & & \multirow[t]{2}{*}{$\mathrm{CeO}_{2}$} & \multirow{2}{*}{$\mathrm{Co}_{3} \mathrm{O}_{4}$} & \multirow[t]{2}{*}{$\mathrm{CoO}$} & \multirow[t]{2}{*}{ Co } & & \multirow{2}{*}{$\mathrm{CeO}_{2}$ surface } & \multicolumn{2}{|c|}{$\mathrm{Co}_{3} \mathrm{O}_{4}$} \\
\hline & & & & & & & & & & $\alpha$ & $\beta$ \\
\hline $\mathrm{Co}_{3} \mathrm{O}_{4}$ & & & $\mathrm{Co}_{3} \mathrm{O}_{4}$ & - & 8.2 & - & - & 100 & - & 281 & 390 \\
\hline $\mathrm{CeO}_{2}$ & & & $\mathrm{CeO}_{2}$ & 6.0 & - & - & - & 64 & 503 & - & - \\
\hline $\mathrm{CeO}_{2}-\mathrm{Co}_{3} \mathrm{O}_{4}-\mathrm{C} 350$ & & 350 & $\mathrm{CeO}_{2}, \mathrm{Co}_{3} \mathrm{O}_{4}$ & 6.0 & 9.8 & - & - & 60 & - & 312 & 375 \\
\hline $\mathrm{CeO}_{2}-\mathrm{Co}_{3} \mathrm{O}_{4}-\mathrm{C} 550$ & & 550 & $\mathrm{CeO}_{2}, \mathrm{Co}_{3} \mathrm{O}_{4}$ & 6.0 & 9.8 & - & - & 31 & - & 333 & 380 \\
\hline $\mathrm{CeO}_{2}-\mathrm{Co}_{3} \mathrm{O}_{4}-\mathrm{R} 200$ & 200 & & $\mathrm{CeO}_{2}, \mathrm{Co}_{3} \mathrm{O}_{4}, \mathrm{CoO}$ & 6.0 & 8.0 & 8.3 & - & 109 & - & 260 & 360 \\
\hline $\mathrm{CeO}_{2}-\mathrm{Co}_{3} \mathrm{O}_{4}-\mathrm{R} 400$ & 400 & & $\mathrm{CeO}_{2}, \mathrm{CoO}, \mathrm{Co}$ & 6.0 & - & 9.4 & 6.2 & 40 & - & - & 290 \\
\hline
\end{tabular}

\footnotetext{
${ }^{a}$ Phases from XRD data by JCPDS pattern; ${ }^{b}$ Calculated the Scherrer equation according to the diffraction peaks.
} 

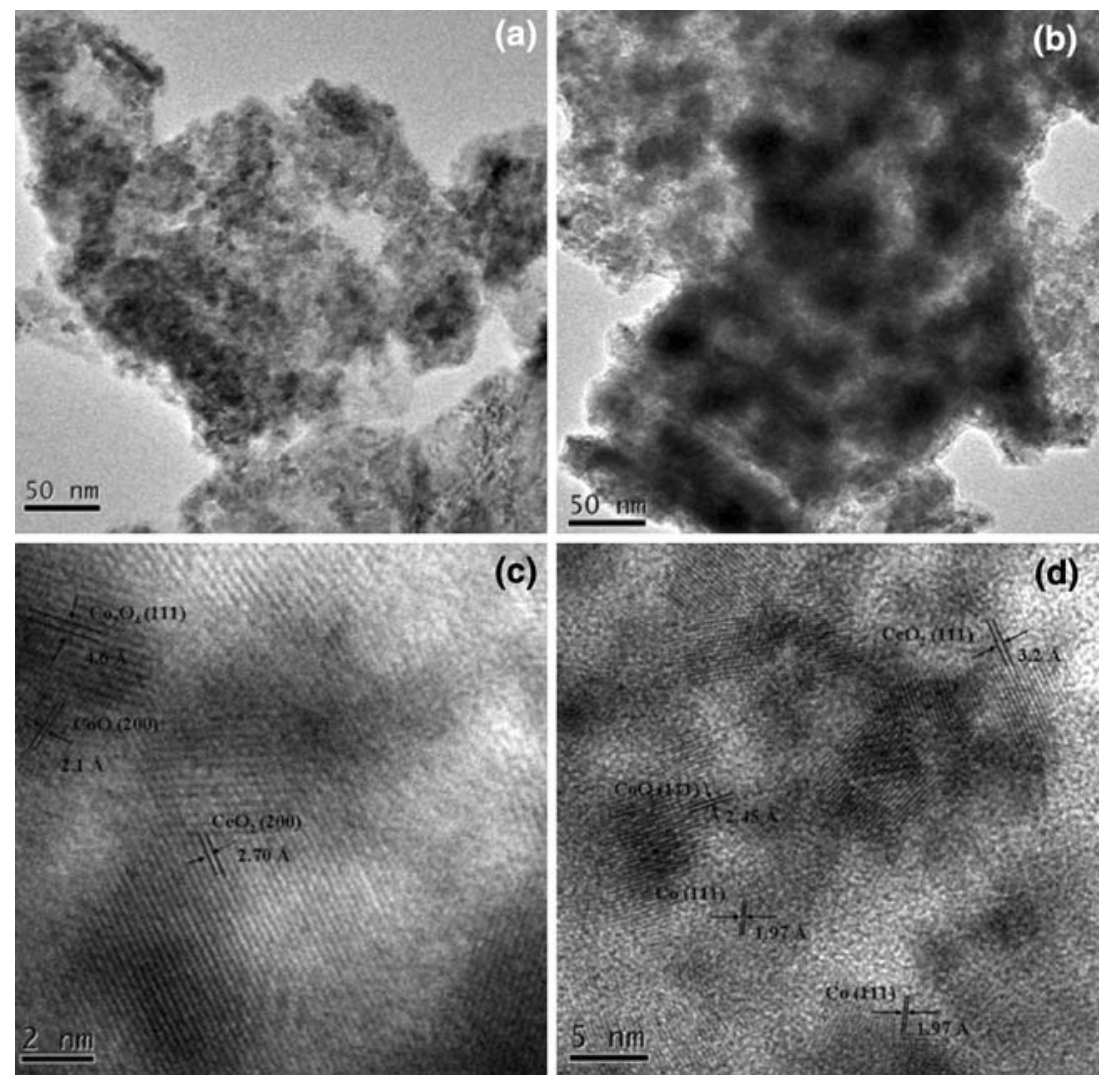

Figure 5. Microscopy images of $\mathrm{CeO}_{2}-\mathrm{Co}_{3} \mathrm{O}_{4}$ binary oxides: (a) TEM image of $\mathrm{CeO}_{2}-\mathrm{Co}_{3} \mathrm{O}_{4}-\mathrm{R} 200$; (b) TEM image of $\mathrm{CeO}_{2}-\mathrm{Co}_{3} \mathrm{O}_{4}-\mathrm{R}_{400}$;

(c) HRTEM image of $\mathrm{CeO}_{2}-\mathrm{Co}_{3} \mathrm{O}_{4}-\mathrm{R} 200$; (d) HRTEM image of $\mathrm{CeO}_{2}-\mathrm{Co}_{3} \mathrm{O}_{4}-\mathrm{R} 400$.

binary oxides, HRTEM analyses are performed and show in figure $5(\mathrm{c})\left[\mathrm{CeO}_{2}-\mathrm{Co}_{3} \mathrm{O}_{4}-\mathrm{R} 200\right]$ and (d) $\left[\mathrm{CeO}_{2}-\right.$ $\left.\mathrm{Co}_{3} \mathrm{O}_{4}-\mathrm{R} 400\right]$. Different lattice fringe patterns are observed for both samples. The labeled species in figure 5(c) corresponds to $\mathrm{Co}_{3} \mathrm{O}_{4}$ [lattice fringe at $4.6 \AA$ for (111) plane], $\mathrm{CoO}$ [lattice fringe at $2.1 \AA$ for (200) plane] and $\mathrm{CeO}_{2}$ [lattice fringe at $2.70 \AA$ for (200) plane]. Whereas the labeled species in figure 5(d) shows other components: $\mathrm{CoO}$ [lattice fringe at $2.45 \AA$ for (111) plane], Co [lattice fringe at $1.97 \AA$ for (111) plane] and $\mathrm{CeO}_{2}$ [lattice fringe at $3.2 \AA$ for (111) plane]. These results are in good agreement with those obtained from XRD analysis.

Figure 6 shows the IR transmittance spectra of ceria, cobaltic oxide and the $\mathrm{CeO}_{2}-\mathrm{Co}_{3} \mathrm{O}_{4}$ binary oxides. All samples except $\mathrm{CeO}_{2}$ and $\mathrm{CeO}_{2}-\mathrm{Co}_{3} \mathrm{O}_{4}-\mathrm{R} 400$ [figure 5(a) and (f)] show two distinct bands at 575-578 $\left(v_{1}\right)$ and $660-663\left(v_{2}\right) \mathrm{cm}^{-1}$ that originated by the stretching vibrations of the $\mathrm{Co}-\mathrm{O}$ bond of cobaltic oxide $[24,26,27]$. The $v_{1}$ band is characteristic of $\mathrm{OB}_{3}^{\mathrm{os}}$ (where $\mathrm{B}^{\text {os }}$ denotes the $\mathrm{Co}^{3+}$ in octahedral hole) vibration and the $v_{2}$ band is attributed to the $\mathrm{A}^{\text {ts }} \mathrm{B}^{\text {os }} \mathrm{O}_{3}$ (where $\mathrm{A}^{\text {ts }}$ denotes the $\mathrm{Co}^{2+}$ in tetrahedral hole) vibration in the spinel lattice $[24,28,29]$. At the same time, the two bands shift apparently to a lower wavenumber for $\mathrm{CeO}_{2}-$ $\mathrm{Co}_{3} \mathrm{O}_{4}-\mathrm{R} 200$ [figure 6(e)] due to the surface of smaller nanoparticle (higher surface area) crystals to weaken the
$\mathrm{Co}-\mathrm{O}$ bond strength. The redistribution of free electrons between the surface and the bulk cause a decrease of the bond force constant, and consequently absorption red shifts.

The DRS spectral features are sensitive to nano-sized oxide particles [30]. The existence of $\mathrm{Co}_{3} \mathrm{O}_{4}$ is further confirmed by the DRS spectroscopy. The DRS spectra of ceria, cobaltic oxide and the $\mathrm{CeO}_{2}-\mathrm{Co}_{3} \mathrm{O}_{4}$ binary oxides are shown in figure 7 . Both maxima characteristic bands at 720 and $420 \mathrm{~nm}$ [see figure 7(b)-(e)] are due to the existence of $\mathrm{Co}_{3} \mathrm{O}_{4}[24,31,32]$ where a migration to octahedral sites occurs. Herein it is worth noting that these bands become more intense as the surface area of catalyst increased. Pure $\mathrm{CeO}_{2}$ [figure 7(a)] shows a broad absorption feature with an absorption edge around $400 \mathrm{~nm}$ characteristic of the semiconducting nature $[33,34]$. The maximum characteristic band for pure $\mathrm{CeO}_{2}$ or $\mathrm{CeO}_{2}-\mathrm{Co}_{3} \mathrm{O}_{4}$ binary oxides at $305 \mathrm{~nm}$ [see figure 7(a) and (c)-(f)] corresponds to the localized $\mathrm{O}$ $\rightarrow$ Ce charge transfer transition involving a number of surface $\mathrm{Ce}^{4+}$ ions. Therefore the DRS results are in good agreement with XRD and IR analysis.

In order to understand the $\mathrm{Co}-\mathrm{O}$ bond strength of $\mathrm{CeO}_{2}-\mathrm{Co}_{3} \mathrm{O}_{4}$ binary oxides, further diagnosed with TPR technique to understand the reduction behavior of $\mathrm{CeO}_{2}-\mathrm{Co}_{3} \mathrm{O}_{4}$ binary oxides. Figure 8 shows the TPR profiles for ceria, cobaltic oxide and the $\mathrm{CeO}_{2}-\mathrm{Co}_{3} \mathrm{O}_{4}$ 


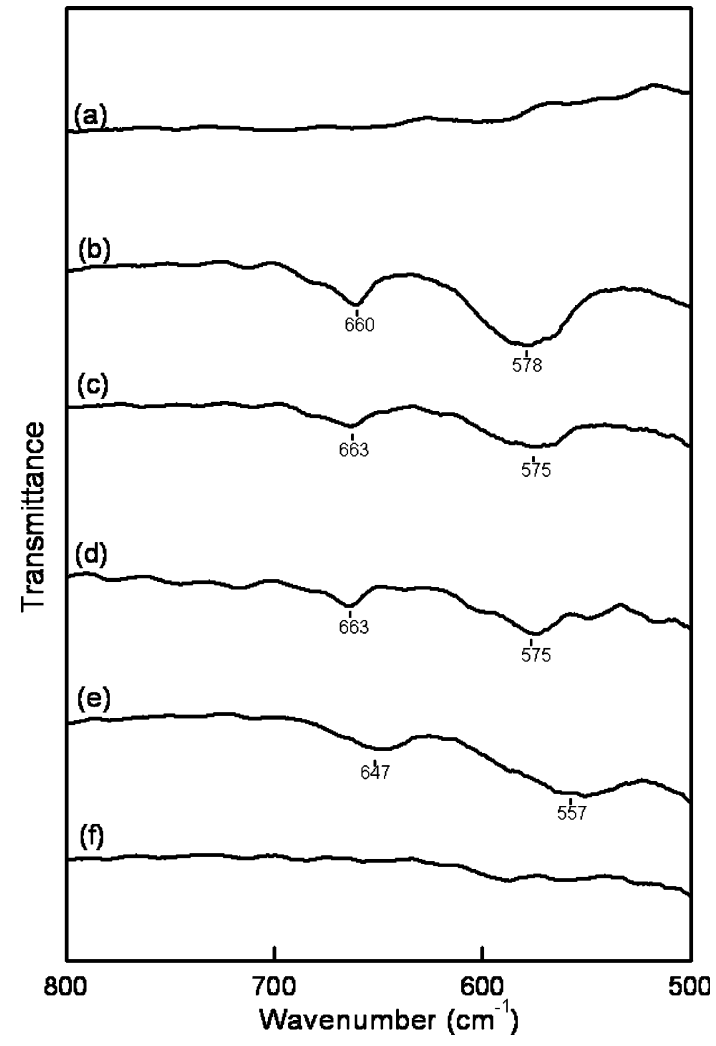

Figure 6. The IR characterization of ceria, cobaltic oxide and the $\mathrm{CeO}_{2}-\mathrm{Co}_{3} \mathrm{O}_{4}$ binary oxides: (a) $\mathrm{CeO}_{2}$; (b) $\mathrm{Co}_{3} \mathrm{O}_{4}$; (c) $\mathrm{CeO}_{2}-\mathrm{Co}_{3} \mathrm{O}_{4-}$ $\mathrm{C} 350$; (d) $\mathrm{CeO}_{2}-\mathrm{Co}_{3} \mathrm{O}_{4}-\mathrm{C} 550$; (e) $\mathrm{CeO}_{2}-\mathrm{Co}_{3} \mathrm{O}_{4}-\mathrm{R} 200$; (f) $\mathrm{CeO}_{2}-$ $\mathrm{Co}_{3} \mathrm{O}_{4}-\mathrm{R} 400$.

binary oxides. All the samples except $\mathrm{CeO}_{2}$ and $\mathrm{CeO}_{2}$ $\mathrm{Co}_{3} \mathrm{O}_{4}-\mathrm{R} 400$ [figure 8(a) and (f)] exhibit a similar TPR profile, consisting of two well-resolved reduction peaks (assigned as $\alpha$ peak and $\beta$ peak). These profiles point to a two-step reduction process: the first one ( $\alpha$ peak) of low intensity, starts at low temperature and overlaps with the more intense second one ( $\beta$ peak). According to the literature $[8,10,20,35,36]$, with the subsequent structural change to $\mathrm{CoO}$, which followed the highertemperature $\beta$ peak and is due to the reduction of $\mathrm{CoO}$ to metallic cobalt [equation (2)].

$$
\begin{gathered}
\mathrm{Co}_{3} \mathrm{O}_{4}+\mathrm{H}_{2} \rightarrow 3 \mathrm{CoO}+\mathrm{H}_{2} \mathrm{O} \\
\mathrm{CoO}+\mathrm{H}_{2} \rightarrow \mathrm{Co}+\mathrm{H}_{2} \mathrm{O}
\end{gathered}
$$

As can be seen in figure 8(b)-(e) and the last two columns of table 1, apparently shift of the $\alpha$ peak and $\beta$ peak appears under different treatments which are relationship with the surface area of binary oxides. Compared to the S.A. (the 9 th column of table 1), both the $\alpha$ peak and $\beta$ peak shift to lower temperatures as the surface area increases, i.e., the $\alpha$ peak and $\beta$ peak of $\mathrm{CeO}_{2}-\mathrm{Co}_{3} \mathrm{O}_{4}-\mathrm{R} 200$ binary oxide (S.A. $=109 \mathrm{~m}^{2} \mathrm{~g}^{-1}$ ) is 260 and $360{ }^{\circ} \mathrm{C}$ [figure 8(e)], respectively. While, the $\alpha$ peak and $\beta$ peak of $\mathrm{CeO}_{2}-\mathrm{Co}_{3} \mathrm{O}_{4}-\mathrm{C} 550$ binary oxide (S.A. $=31 \mathrm{~m}^{2} \mathrm{~g}^{-1}$ ) is 333 and $380{ }^{\circ} \mathrm{C}$ [figure $8(\mathrm{~d})$ ],

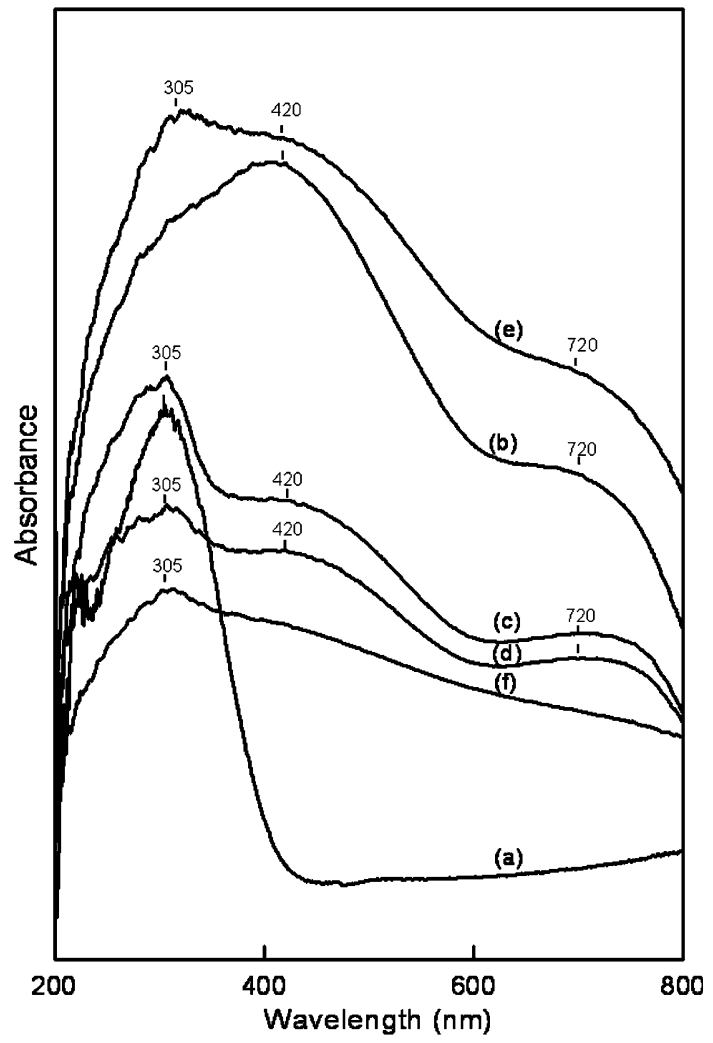

Figure 7. The DRS spectra of ceria, cobaltic oxide and the $\mathrm{CeO}_{2}-$ $\mathrm{Co}_{3} \mathrm{O}_{4}$ binary oxides: (a) $\mathrm{CeO}_{2}$; (b) $\mathrm{Co}_{3} \mathrm{O}_{4}$; (c) $\mathrm{CeO}_{2}-\mathrm{Co}_{3} \mathrm{O}_{4}-\mathrm{C} 350$; (d) $\mathrm{CeO}_{2}-\mathrm{Co}_{3} \mathrm{O}_{4}-\mathrm{C} 550$; (e) $\mathrm{CeO}_{2}-\mathrm{Co}_{3} \mathrm{O}_{4}-\mathrm{R} 200$; (f) $\mathrm{CeO}_{2}-\mathrm{Co}_{3} \mathrm{O}_{4}-\mathrm{R} 400$.

respectively. These results indicate that the increasing of surface area of $\mathrm{CeO}_{2}-\mathrm{Co}_{3} \mathrm{O}_{4}$ binary oxides can weaken the bond strength of $\mathrm{Co}-\mathrm{O}$ and promote more lattice oxygen desorbed from $\mathrm{Co}_{3} \mathrm{O}_{4}$ to decrease the reduction temperature. Aside from the consecutive reduction of $\mathrm{Co}_{3} \mathrm{O}_{4}$, a reduction peak with lower intensity at $503{ }^{\circ} \mathrm{C}$ [figure 8(a)] is presented for pure $\mathrm{CeO}_{2}$. The peak is attributed to the removal of surface capping oxygen ions during the reduction reaction [37,38]. Moreover, the reduction behavior of $\beta$ peak in $\mathrm{CeO}_{2}-\mathrm{Co}_{3} \mathrm{O}_{4}$ binary oxides [figure 8(c)-(e)] and pure $\mathrm{Co}_{3} \mathrm{O}_{4}$ [figure 8(b)] are some different. The tailing $\beta$ peak in $\mathrm{CeO}_{2}-\mathrm{Co}_{3} \mathrm{O}_{4}$ binary oxides is attributed to the reduction of capping oxygen of ceria. From the shift of reduction temperatures, the combined effect between the $\mathrm{CeO}_{2}$ and $\mathrm{Co}_{3} \mathrm{O}_{4}$ is more evident for the low temperature reduction treated $\mathrm{CeO}_{2}-$ $\mathrm{Co}_{3} \mathrm{O}_{4}-\mathrm{R} 200$ binary oxides. Also, it is interesting to compare the reduction behavior of $\mathrm{CeO}_{2}-\mathrm{Co}_{3} \mathrm{O}_{4}-\mathrm{R} 400$ and $\mathrm{CeO}_{2}-\mathrm{Co}_{3} \mathrm{O}_{4}-\mathrm{R} 200$ binary oxides. This is in agreement with the results of XRD analysis. Different mixed phases obtained under reducing conditions give various diffraction patterns and reduction behavior. A consecutive reduction for $\mathrm{Co}_{3} \mathrm{O}_{4}$ species [exist in $\mathrm{CeO}_{2}-\mathrm{Co}_{3} \mathrm{O}_{4}-$ R200 sample, see figures 3(a) and 8(e)] and a single peak for $\mathrm{CoO}$ at $290{ }^{\circ} \mathrm{C}$ [exist in $\mathrm{CeO}_{2}-\mathrm{Co}_{3} \mathrm{O}_{4}-\mathrm{R} 400$ binary oxides, see figures 3(b) and 8(f)] are observed separately. Since via $400{ }^{\circ} \mathrm{C}$ reducing condition has removed the 


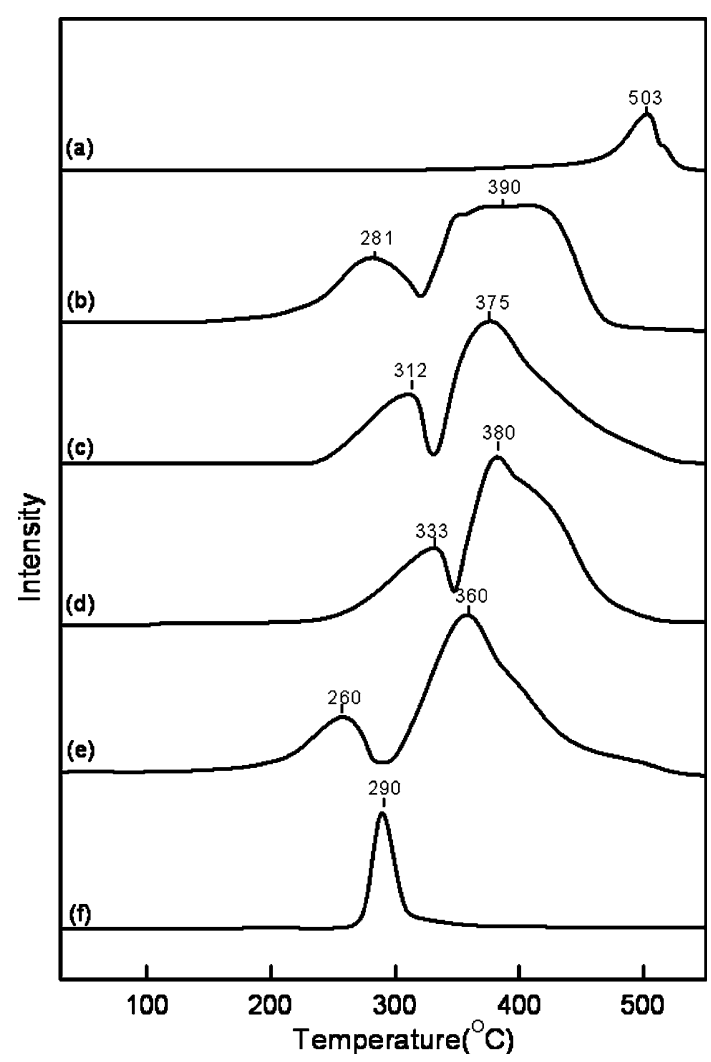

Figure 8. The TPR profiles of ceria, cobaltic oxide and the $\mathrm{CeO}_{2}$ $\mathrm{Co}_{3} \mathrm{O}_{4}$ binary oxides: (a) $\mathrm{CeO}_{2}$; (b) $\mathrm{Co}_{3} \mathrm{O}_{4}$; (c) $\mathrm{CeO}_{2}-\mathrm{Co}_{3} \mathrm{O}_{4}-\mathrm{C} 350$; (d) $\mathrm{CeO}_{2}-\mathrm{Co}_{3} \mathrm{O}_{4}-\mathrm{C} 550$; (e) $\mathrm{CeO}_{2}-\mathrm{Co}_{3} \mathrm{O}_{4}-\mathrm{R} 200$; (f) $\mathrm{CeO}_{2}-\mathrm{Co}_{3} \mathrm{O}_{4}-\mathrm{R} 400$.

capping oxygen of ceria, no tailing peak occurs in $\mathrm{CeO}_{2}-$ $\mathrm{Co}_{3} \mathrm{O}_{4}-\mathrm{R} 400$ binary oxides.

\section{Conclusion}

A series of $\mathrm{CeO}_{2}-\mathrm{Co}_{3} \mathrm{O}_{4}$ binary oxides have been obtained by different pretreatment conditions and characterized. The following conclusions are displayed:

(1) Phase components of $\mathrm{CeO}_{2}-\mathrm{Co}_{3} \mathrm{O}_{4}$ binary oxides and surface area can be controlled under optimized pretreatment.

(2) The $\mathrm{CeO}_{2}-\mathrm{Co}_{3} \mathrm{O}_{4}$ binary oxides possess larger surface area under low-temperatures pretreatment, i.e., $\mathrm{CeO}_{2}-\mathrm{Co}_{3} \mathrm{O}_{4}-\mathrm{R} 200\left(\right.$ S.A. $\left.=109 \mathrm{~m}^{2} \mathrm{~g}^{-1}\right)>\mathrm{CeO}_{2}-$ $\mathrm{Co}_{3} \mathrm{O}_{4}-\mathrm{R} 400$ (S.A. $\left.=40 \mathrm{~m}^{2} \mathrm{~g}^{-1}\right)$.

(3) Phase components of $\mathrm{CeO}_{2}-\mathrm{Co}_{3} \mathrm{O}_{4}$ binary oxides are transferred upon the treating temperature, i.e., the $\mathrm{CeO}_{2}-\mathrm{Co}_{3} \mathrm{O}_{4}-\mathrm{R} 200$ binary oxide exhibits $\mathrm{CeO}_{2}$, $\mathrm{Co}_{3} \mathrm{O}_{4}$ and $\mathrm{CoO}$, while, the $\mathrm{CeO}_{2}-\mathrm{Co}_{3} \mathrm{O}_{4}-\mathrm{R} 400$ binary oxide exhibits $\mathrm{CeO}_{2}, \mathrm{CoO}$ and $\mathrm{Co}$.

\section{Acknowledgments}

We are pleased to acknowledge financial supports for this study from Academia Sinica and the National Science Council of the Republic of China.

\section{References}

[1] S.D. Gardner, G.B. Hoflund, D.R. Schryer, J. Schryer, B.T. Upchurch and E.J. Kielin, Langumir 7 (1991) 2135.

[2] D.L. Trimm, Appl. Catal. A 7 (1983) 249.

[3] A.B. Lamb, C. Bray and J.C.W. Fraser, Ind. Eng. Chem. 12 (1920) 213.

[4] H. Yamaura, K. Moriya, N. Miura and N. Yamazoe, Sens. Actuators B 65 (2000) 39.

[5] D.R. Schryer, B.T. Upchurch, B.D. Sidney, K.G. Bromn, G.B. Hoflund and P.K. Herz, J. Catal. 130 (1991) 314.

[6] Y. Kim, S.K. Shi and J.H. White, J. Catal. 61 (1980) 61.

[7] M. Olsbye, R. Wendelbo and T. Akporiayc, Appl. Catal. A 152 (1997) 127.

[8] H.K. Lin, C.B. Wang, H.C. Chiu and S.H. Chien, Catal. Lett. 86 (2003) 63

[9] H.K. Lin, H.C. Chiu, H.C. Tsai, S.H. Chien and C.B. Wang, Catal. Lett. 88 (2003) 169.

[10] C.B. Wang, C.W. Tang, S.J. Gau and S.H. Chien, Catal. Lett. 101 (2005) 59.

[11] P. Broqvist, I. Panas and H. Person, J. Catal. 210 (2002) 198.

[12] M. Haneda, Y. Kintaichi, N. Bion and H. Hamada, Appl. Catal. B 46 (2003) 473.

[13] B.A. Sazonov, V.V. Popovskii and G.K. Boreskov, Kinet. Catal. 9 (1968) 255.

[14] D.S. Lafyatis, G.P. Ansell, S.C. Bennett, J.C. Frost, P.J. Millington, R.R. Rajaram, A.P. Walker and T.H. Ballinger, Appl. Catal. B 18 (1998) 123.

[15] A. Martinez-Arias, M. Fernandez-Garcia, O. Galvez, J.M. Coronado, J.A. Anderson, J.C. Conesa, J. Soria and G. Munuera, J. Catal. 195 (2000) 207.

[16] M.A. Centeno, C. Portales, I. Carrizosa and J.A. Odriozola, Catal. Lett. 102 (2005) 289.

[17] W. Liu and F.S. Maria, J. Catal. 153 (1995) 304.

[18] U. Oran and D. Uner, Appl. Catal. B 54 (2004) 183.

[19] M.F. Luo, Y.J. Zhong, X.X. Yuan and X.M. Zheng, Appl. Catal. A 162 (1997) 121.

[20] M. Kang, M.W. Song and C.H. Lee, Appl. Catal. A 251 (2003) 143.

[21] A. Trovarelli, Catal. Rev. 38 (1996) 439.

[22] A. Martinez-Arias, M. Fernandez-Garcia, J. Soria and J.C. Conesa, J. Catal. 182 (1999) 367.

[23] M.M. Natile and A. Glisenti, Chem. Mater. 15 (2003) 2502.

[24] C.W. Tang, C.C. Kuo, M.C. Kuo, C.B. Wang and S.H. Chien, Appl. Catal. A 309 (2006) 37.

[25] G.A. El-Shobaky and N.M. Deraz, Mater. Lett. 47 (2001) 231.

[26] C. Spenser and D. Schroeder, Phys. Rev. B 9 (1974) 3658.

[27] T. Andrushkevich, G. Boreskov, V. Popovskii, L. Pliasova, L. Karakchiev and A. Ostankovitch, Kinet. Katal. 6 (1968) 1244.

[28] St.G. Christoskova, M. Stoyanova, M. Georgieva and D. Mehandjiev, Mater. Chem. Phys. 60 (1999) 39.

[29] R.N. Singh, J.P. Pandey, N.K. Singh, B. Lal, P. Chartier and J.F. Koenig, Electrochim. Acta 45 (2000) 1911.

[30] B.M. Weckhuysen and R.A. Schoonheydt, Catal. Today 49 (1999) 441.

[31] M. Lojacono, A. Cimino and G.C.A. Schuit, Gazz. Chim. Ital. 103 (1973) 1281.

[32] F.J. Gillambias, A.L. Agudo and V. Rives-Arnau, J. Mater. Sci. 17 (1982) 936.

[33] S.P. Tandon and J.P. Gupta, Phys. Stat. Sol. 38 (1970) 363.

[34] A. Bensalem, F.B. Verduraz, M. Delamar and G. Bugli, Appl. Catal. A 121 (1995) 81.

[35] P. Arnoldy and J.A. Moulijn, J. Catal. 93 (1985) 38.

[36] M. Vo $\beta$, D. Borgmann and G. Wedler, J. Catal. 212 (2002) 10.

[37] G.R. Rao, H.R. Sahu and B.G. Mishra, Colloids surf. A 220 (2003) 261.

[38] X.C. Zheng, S.P. Wang, X.Y. Wang, S.R. Wang, X.G. Wang and S.H. Wu, Mater. Lett. 59 (2005) 2769. 